\title{
Keputusan Manajemen Memediasi Pengaruh Gross Profit Margin Terhadap Benchmarking Agresivitas Pajak
}

\author{
Santi Sani ${ }^{1}$, Surtikanti ${ }^{2}$ \\ ${ }^{1}$ Universitas Pancasila, Jl. Srengseng Sawah, Jagakarsa, Jakarta Selatan, 12640 \\ ${ }^{2}$ Universitas Ilmu Komputer Bandung (Unikom), Jl. Dipatiukur No. 112-116, Bandung, Jawa Barat 40132
}

INFO ARTIKEL

\section{JEL Classsification:}

M41

H25

Keywords:

gross profit margin,

financial leverage,

dividend policy, tax

aggressiveness.

\begin{abstract}
A B S T R A C T
The aim of research to determine how much influence the gross profit margin on a tax aggressiveness benchmarking with pemediasi management decisions. Correlational quantitative research methods with PLS regression analysis techniques SmartPLS 3.0 program and selection of samples by purposive sampling methodThe results showed a significant influence between the gross profit margin on a tax aggressiveness mediated management decisions in this case financial leverage and dividend policy. Contributions of research can provide a signal to the fund owner (shareholder) the placement of capital in companies that commit acts of tax aggressiveness, and the regulator can be considered the formulation of the rules-setting debt and dividends related to the effect of tax payments arising from tax aggressiveness action.
\end{abstract}

\begin{abstract}
A B S T RA K
Tujuan penelitian untuk mengetahui seberapa besar pengaruh gross profit margin terhadap benchmarking agresivitas pajak dengan pemediasi keputusan manajemen. Metode penelitian kuantitif korelasional dengan tehnik analisis regresi PLS program SmartPLS 3.0 dan pemilihan sampel dengan metode purposive sampling. Hasil penelitian menunjukkan pengaruh yang signifikan antara gross profit margin terhadap agresivitas pajak dimediasi keputusan manajemen dalam hal ini financial leverage dan kebijakan dividen. Kontribusi penelitian dapat memberikan signal terhadap pemilik dana (shareholder) terhadap penempatan modal pada perusahaan yang melakukan tindakan agresivitas pajak, dan bagi regulator dapat menjadi pertimbangan perumusan peraturan penetapan hutang dan dividen terkait dengan efek pembayaran pajak yang ditimbulkan dari tindakan agresivitas pajak.
\end{abstract}

\section{Pendahuluan}

Pajak adalah beban bagi perusahaan maka wajar jika tidak satupun perusahaan (wajib pajak dengan senang hati dan suka rela membayar pajak). Usaha-usaha yang dilakukan perusahaan untuk mengurangi beban pajak disebut sebagai tindakan agresivitas pajak (tax aggressiveness). Tax aggressiveness adalah tindakan manipulasi untuk menurunkan penghasilan kena pajak melalui perencanaan pajak, baik yang berhubungan dengan tax evasion maupun tidak (Frank et al., 2009).

Gross profitmargin menggambarkan kondisi laba bruto perusahaan sebelum dikurangi biaya bunga dan biaya manajemen menjadi dasar awal

*Email Korespondensi: ${ }^{1}$ sani.santi@gmail.com, ${ }^{2}$ kanti_haidar@yahoo.com 
sebelum penetapan laba kena pajak, pembayaran pajak yang berimbas dari laba yang dihasilkan mendorong perusahaan mengambil keputusan dengan memanfaatkan peraturan perpajakan yang dapat meminimalkan pajak sebagai salah satu bentuk penghindaran pajak (agresivitas pajak). Keputusan manajemen tersebut antara lain adalah financial leverage dan kebijakan dividen.

Pengaruh gross profit margin terhadap agresivitas pajak yang dimediasi oleh keputusan manajemen dapat tergambar dari beberapa fenomena yang terjadi. Fenomene yang terjadi dalam perusahaan food and beverage tahun 20102015 terlihat dari adanya tindakan agresivitas pajak yang ditunjukkan oleh net profit margin yang dihasilkan perusahaan masih lebih rendah dibandingkan dengan net profit margin standar yang ditetapkan oleh Direktorat Jenderal Pajak sebagaimana terlihat pada gambar :

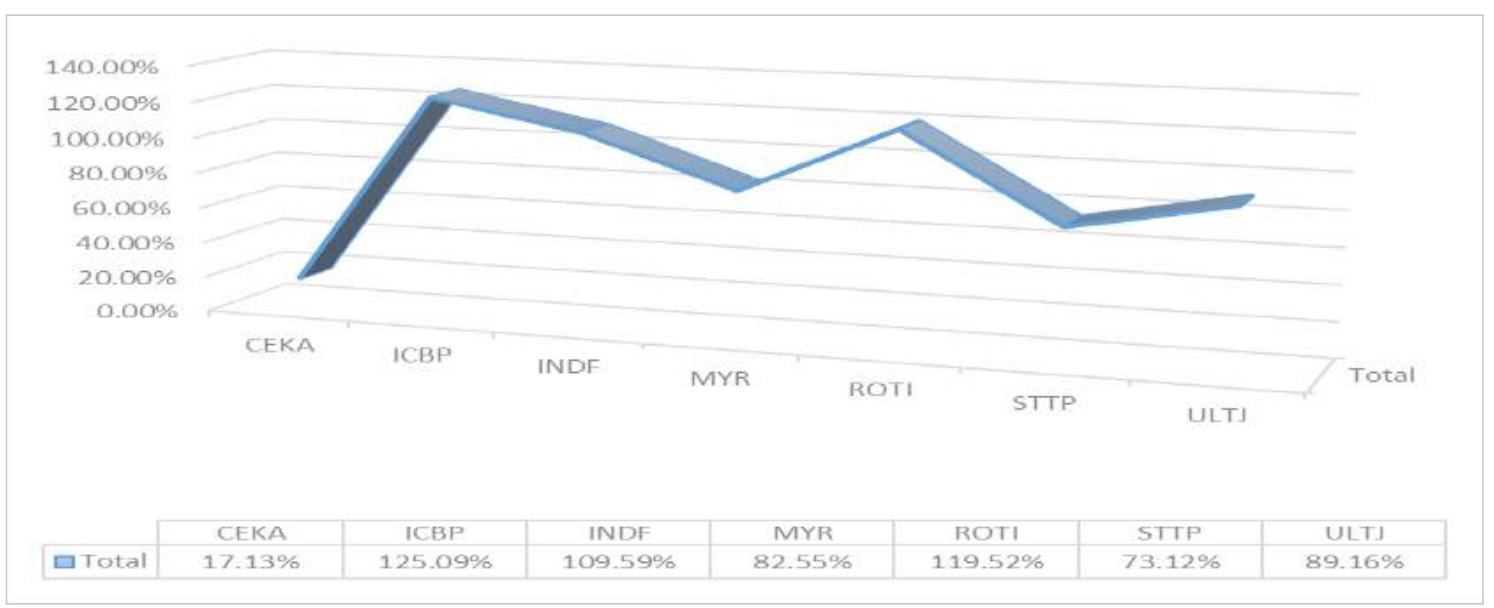

Sumber : Data sekunder yang diolah dalam penelitian

\section{Gambar 1. Rata-rata agresivitas pajak perusahan}

Fenomena yang kedua menunjukkan ratarata gross profit yang dihasilkan bervariasi umumnya tidak lebih dari $30 \%$, hanya ada satu perusahaan yang mencapai $48 \%$, namun ada yang paling rendah yaitu $11 \%$ sebagaimana terlihat pada gambar 2 .

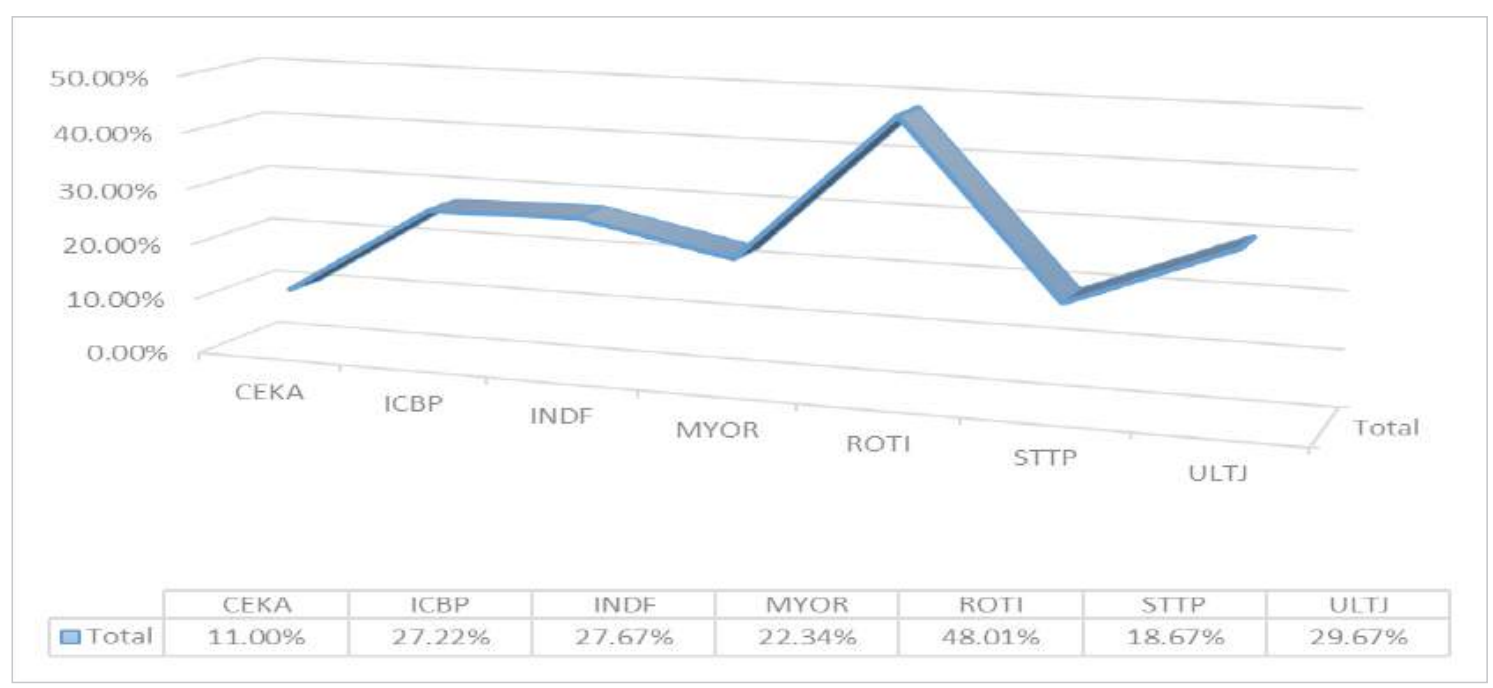

Sumber : data yang diolah dalam penelitian

Gambar 2. Gross profit margin perusahan food and beverage 
Fenomena tingkat agresivitas pajak yang berawal dari gross profit margin yang dihasilkan perusahaan tentunya tidak akan terlepas dari keputusan managemen yang diambil perusahaan. Keputusan manajemen dalam penelitian ini adalah financial leverage dan kebijakan dividen yang diambil oleh perusahaan. Fenomena menunjukkan bahwa pendanaan perusahaan ratarata sebagian besar melalui hutang dibandingkan modal yang ada. Berbeda hal dengan keputusan financial leverage dibandingkan dengan kebijakan dividen, karena pada kenyataannya menunjukkan tidak semua perusahaan dalam kondisi laba melakukan kebijakan dividen ditahun tersebut.

Dari fenomena diatas adanya hubungan profitabilitas dengan agresivitas pajak telah dilakukan oleh beberapa peneliti sebelumnya antara lain Sabrina dan Soepriyanto (2013) dan Kurniasih dan Sari (2013) yang menyatakan ROA berpengaruh signifikan terhadap agresivitas pajak perusahaan. Grupta dan Newberry (1997) dalam Yoena (2013) bahwa kenaikan ROA akan mengakibatkan kenaikan ETR, sehingga ROA memiliki hubungan yang postif dengan ETR. Berbeda halnya dengan penelitian yang dilakukan oleh Zulaikha (2014) yang menunjukkan bahwa ROA berpengaruh tidak signifikan terhadap agresivitas pajak (effective tax ratio).

Penelitian profitabilitas terhadap kebijakan hutang menghasilkan pendapat yang berbedabeda, Ismiyati dan Hanafi (2003) dan Indah Ningrum dan Handayani (2009) menjelaskan hubungan yang negatif, dimana pada tingkat profitabilitas rendah, perusahaan menggunakan hutang untuk membiayai operasional. Namun Berbeda dengan penelitian Masdupi (2005) dengan hasil yang tidak signifikan antara profitabilitas terhadap kebijakan hutang.

Penelitian yang dilakukan oleh Sari dan Martani (2010) menunjukkan hubungan yang positif tidak signifikan antara financial leverage dengan agresivitas pajak (ETR, CETR). Pendapat yang sama terkait signifikansi antara penggunaan hutang dengan agresivitas pajak (NPM) juga dilakukan dalam penelitian yang dilakukan oleh Adisamarta dan Naniek (2015), Fikriyah (2012), Ngadiman dan Puspitasari (2014) yang menunjukkan hubungan yang negatif tidak signifikan, Berbeda dengan penelitian yang dilakukan oleh Suyanto dan Supramono (2011), Ozkon (2001) dan Choi (2003) yang menunjukkan hasil yang positif signifikan antara penggunaan hutang dengan agresivitas pajak (ETR, CTR),

Penelitian yang ada sebelumnya menyatakan bahwa profitabilitas berpengaruh postif terhadap kebijakan dividen (Marpaung,2009), Nanastassiou (2007), Suharli (2007), berbeda dengan yang dihasilkan oleh Anil dan Kapoor (2008) yang menyatakan bahwa pengaruh profitabilitas terhadap kebijakan dividen positif tidak signifikan.

Adapun yang membedakan penelitian ini dengan penelitian sebelumnya adalah penggunaan skala pengukuran agresivitas pajak perusahaan, dalam penelitianinimembandingkan net profit magin dari perusahaan dengan net profit margin dari perusahaan sejenis, dan untuk net profit margin dari perusahaan sejenis didasarkan oleh penetapan rasio benchmarking yang dikeluarkan oleh Direktorat Jenderal Pajak, selain itu penelitian kebijakan dividen terhadap pajak yang pernah dilakukan hanya menjelaskan hubungan secara kualitatif tanpa adanya penelitian secara kuantitatif yang menunjukkan tingkat signifikansi antara kebijakan dividen dengan agresivitas pajak.

\section{Telaah Teori dan Pengembangan Hipotesis}

Agresivitas pajak yang dilakukan perusahaan terkait terhadap tindakan perusahaan untuk menurunkan laba kena pajak baik dilakukan secara legal maupun illegal yang tentunya berimbas kepada penghematan pajak bagi perusahaan dan peminimalan jumlah pajak yang dibayar. Hubungan antara laba dengan pembayaran pajak tidak terlepas 
dengan keputusan perusahaan untuk melakukan keputusan manajemen baik dari segi prioritas pendanaan maupun keputusan pembagian dividen kepada pemegang saham.

Pecking order theory yang dikemukakan oleh Myers dan Majluf (1984) menjelaskan mengapa perusahaan yang profitable umumnya menggunakan utang dalam jumlah yang sedikit. Hal tersebut bukan disebabkan karena perusahaan mempunyai target leverage yang rendah, tetapi karena mereka memerlukan external financing yang sedikit. Perusahaan yang kurang profitable akan cenderung menggunakan utang yang lebih besar karena dua alasan, yaitu; (1) dana internal tidak mencukupi, dan (2) utang merupakan sumber eksternal yang lebih disukai.

Trade-off theory yang diperkenalkan oleh Modigliani \& Miller pada tahun 1958 mengungkapkan bahwa Perusahaan akan berhutang sampai pada tingkat hutang tertentu, dimana penghematan pajak (tax shields) dari tambahan hutang sama dengan biaya kesulitan keuangan (financial distress).

Tindakan pajak agresif adalah tindakan yang ditujukan untuk menurunkan laba kena pajak melalui perencanaan pajak, baik menggunakan cara yang tergolong atau tidak tergolong tax evasion (Frank et.al, 2009) Pengukuran agresivitas pajak diproksikan dengan membandingkan net profit margin (NPM) dalam perusahaan dengan net profit margin (NPM) industri perusahaaan sejenis. Indeks untuk industri sejenis dalam penelitian ini menggunakan dasar hasil penghitungan rasiorasio total benchmarking beberapa klasifikasi usaha (KLU) tertentu yang dikeluarkan dalam Surat Edaran Direktur Jenderal Pajak Nomor : SE-11/PJ/2010 Tentang Penetapan Rasio Total Benchmarking Tahap II dan SE-96/ PJ/2010 Tentang Rasio Total Benchmarking dan Petunjuk dan Pemanfaatannya. Berikut daftar net profit margin yang tertuang dalam Surat Edaran Direkorat Jenderal Pajak terkait dengan perusahaan food and beverage yang digunakan dalam penelitian ini :

Tabel 2. Rasio-rasio total benchmarking beberapa Klu tertentu

\begin{tabular}{llll}
\hline No & Kode Klu & Uraian Klu & Rasio NPM \\
\hline 1 & 15211 & Industri Susu & $13.54 \%$ \\
2 & 15144 & Industri minyak goreng dari kelapa sawit & $32.14 \%$ \\
3 & 15410 & Industri roti dan sejenisnya & $14.27 \%$ \\
4 & 15432 & Industri makanan dari coklat dan kembang gula & $10.35 \%$ \\
\hline
\end{tabular}

Sumber : Surat Edaran Direktorat Jenderal Pajak

Rasio Profitabilitas terdiri atas dua jenis, yaitu rasio yang menunjukkan profitabiltas dalam kaitannya dengan penjualan dan rasio yang menunjukkan profitabilitas dalam kaitannya dengan investasi. Profitabilitas dalam hubungannya dengan penjualan terdiri atas gross profit margin dan net profit margin. Van Horne dan Wachowicz (2005:222). Dalam penelitian ini rasio profitabiltas yang digunakan adalah gross profit margin karena gross profit margin merupakan awal laba perusahaan sebelum diperhitungkan oleh biaya diluar HPP yang antara lain adalah biaya bunga yang muncul dari financial leverage.

Financial leverage ialah kebijakan perusahaan untuk mendanai segala bentuk operasinya dengan menggunakan hutang keuangan. Hutang keuangan ini dilakukan dengan tujuan membiayai aktivitas-aktivitas perusahaan baik dalam hal pengoperasian perusahaan maupun untuk investasi Sukirni (2012).

Kebijakan dividen ialah kebijakan yang berhubungan dengan pembayaran dividen oleh pihak perusahaan, berupa penentuan besarnya dividen yang akan dibagikan dan besarnya 
saldo laba yang ditahan untuk kepentingan perusahaan (Rosdini, 2009). Berdasarkan kerangka pemikiran, maka hipotesis penelitian dirumuskan sebagai berikut :

\section{Pengaruh gross profit margin terhadap financial leverage}

Suatu perusahaan pastinya membutuhkan dana dalam menjalankan usahanya, gross profit margin yang merupakan dari rasio profitabilitas yang berasal dari laba kotor dibandingkan penjualan merupakan laba awal sebelum memperhitungkan biaya manajemen dan biaya yang lainnya. Perusahaan awalnya memilih pendanaan internal (laba ditahan) kemudian hutang dan terakhir ekuitas.

Hubungan negatif antara profitabilitas dengan hutang, dimana kenaikan profit akan mendorong perusahaan menurunkan penggunaan hutang sejalan dengan penelitian yang dilakukan oleh Indahningrum dan Handayani (2009), ismayanti dan hanafi (2003). Myers et al (1984), jensen et al (1992) dan moh'ed et al (1998) dan Nurbaiti (2007).

\section{H1: Gross profit margin berpengaruh ter- hadap financial leverage}

\section{Pengaruh gross profit margin terhadap kebijakan Dividen}

Laba tahun berjalan merupakan salah satu faktor yang mempengaruhi pembayaran dividen saat ini selain dividen tahun sebelumnya (Lintner, 1956). Perusahaan penghasil profit mampu membayar dividen sekaligus menyimpan dana internal berupa laba ditahan untuk membiayai investasinya (Al-Makalwi, 2007) dengan syarat profit yang dihasilkannya cenderung stabil (Atmaja, 2008:292). Selain itu menurut Jensen, Solberg, dan Zorn (1992), semakin tinggi laba maka semakin tinggi aliran kas dalam perusahaan sehingga perusahaan dapat membayar dividen lebih tinggi, hipotesis yang diuji sebagai berikut :

H1: Gross profit margin berpengaruh terhadap kebijakan dividen

\section{Pengaruh financial leverage terhadap agresivitas pajak perusahaan}

Perusahaan dimungkinkan menggunakan utang untuk memenuhi kebutuhan opera-sional dan investasi perusahaan. Akan tetapi, utang akan menimbulkan beban tetap (fixed rate of return) yang disebut dengan bunga. Penelitian Ozkan (2001) memberikan bukti bahwa perusahaan yang memiliki kewajiban pajak tinggi akan memilih untuk berutang agar mengurangi pajak. Dengan sengajanya perusahaan berutang untuk mengurangi beban pajak maka dapat disebutkan bahwa perusahaan tersebut agresif terhadap pajak. Hal ini sejalan dengan penelitian suyanto dan supramono (2012) yang menjelaskan bahwa hutang perusahaan manufaktur berpengaruh positif dan signifikan terhadap agresivitas pajak perusahaan.

H3: Financial leverage berpengaruh terhadap agresivitas pajak

\section{Kebijakan dividen berpengaruh terhadap agresivitas pajak}

Kebijakan dividen yang dilakukan dengan membagikan dividen dari laba yang dihasilkan perusahaan dalam ketentuan perpajakan di indonesia dilakukan dengan melakukan pemotongan pajak dari penghasilan yang diterima pemegang saham dan tidak dapat dibebankan kepada perusahaan. Jadi ada banyak pertimbangan yang dilakukan oleh perusahaan untuk melakukan langkah kebijakan dividen, dalam beberapa penelitian yang dilakukan oleh Prihandini (2012) menjelaskan bahwa pajak badan berpengaruh negatif terhadap kebijakan dividen.

H4: kebijakan dividen berngaruh ter-hadap agresivitas pajak

Pengaruh gross profit margin terhadap agresivitas pajak

Perusahaan yang profitability dengan kenaikan laba kotor yang meningkat merupakan awal yang baik untuk mencerminkan kesehatan 
keuangan peru-sahaan tersebut. Perusahaan dengan profitabilitas yang tinggi akan lebih taat membayar pajak karena perusahaan tersebut tidak memiliki kesulitan dalam memenuhi kewajibannya, baik itu kewajiban kepada investor, kepada kreditor, maupun kepada pemerintah yaitu membayar pajak. Peru-sahaan dengan profitabilitas yang rendah akan memiliki kemungkinan yang tinggi untuk tidak taat membayar pajak. Hal ini karena perusahaan dengan profitabilitas yang rendah akan memilih untuk mem-pertahankan keadaan keuangan dan aset perusahaan daripada membayar pajak, sehingga perusahaan tersebut menjadi agresif terhadap pajak.

Pendapat yang sama juga diungkapan oleh Rodiguez dan Arias (2012) hubungan antara profitabiltas dan effective tax ratio (salah satu alat ukur agresivitas pajak perusahaan) bersifat langsung dan signifikan.

\section{H5: Gross profit margin berpengaruh ter- hadap agresivitas pajak}

\section{Gross profit margin berpengaruh terhadap agresivitas pajak dimediasi oleh financial leverage dan kebijakan dividen}

Situasi dimana perusahaan dengan peningkatan gross profit margin yang tinggi dihadapkan oleh pilihan pembayaran pajak yang meningkat pula. Perusahaan yang profit dengan perencanaan pajak yang baik memungkinkan mencari pola yang terbaik dalam rangka melakukan penghematan pajak. Salah satu penghematan pajak berdasarkan trade-off teory yang diungkap oleh Miier (1958) Perusahaan akan berhutang sampai pada tingkat hutang tertentu, dimana penghematan pajak (tax shields) dari tambahan hutang sama dengan biaya kesulitan keuangan (financial distress)

Hal tersebut membawa implikasi meningkatnya penggunaan utang oleh perusahaan. Penelitian Ozkan (2001) memberikan bukti bahwa perusahaan yang memiliki kewajiban pajak tinggi akan memilih untuk berutang agar menguran- gi pajak. Dengan sengajanya perusahaan berutang untuk mengurangi beban pajak maka dapat disebutkan bahwa perusahaan tersebut agresif terhadap pajak. Hal ini sejalan dengan penelitian Suyanto dan Supramono (2012).

Perusahaan yang profitabile tentu ber-kesempatan untuk membagikan laba kepada pemegang saham. Sesuai teori shareholder adalah seseorang atau badan hukum yang secara sah memiliki satu atau lebih saham pada perusahaan. Sehingga dapat dikatakan bahwa peningkatan profi-tabilitas dalam mendorong perusahaan untuk melakukan kebijakan dividen.

Kebijakan manajemen perusahaan dalam hal mengambil keputusan melakukan alternatif kebijakan dividen tentunya akan berpengaruh terhadap tindakan agresivitas pajak yang dilakukan yang dapat ditunjuk-kan oleh tingkat pembayaran pajak yang dilakukan.

H6: Gross profit margin berpengaruh terhadap agresivitas pajak dimediasi oleh financial leverage dan kebijakan dividen

\section{Metode}

Metode yang digunakan dalam penelitian adalah metode kuantitatif korelasional. Teknik analisis yang akan digunakan adalah analisis regresi Partial Least Square dengan program SmartPLS 3.0. Penelitian ini menggunakan data sekunder yang diperoleh dari beberapa publikasi dari Bursa Efek Indonesia dengan pengambilan data melalui data situs internet www.idx.co.id. Dari populasi perusahaan industri yang terdaftar dipilih sampel dengan metode purposive sampling. Adapun kriteria yang digunakan pada tabel 3 berikut ini : 
Tabel 3. Kriteria pemilihan sampel penelitian

\begin{tabular}{clc}
\hline No & \multicolumn{1}{c}{ Kiteria } & Jumlah \\
\hline 1 & Perusahaan Industri food and beverage terdaftar di Bursa Efek Indonesia (BEI) & 15 \\
2 & Perusahaan industri tidak menerbitkan laporan keuangan secara lengkap dalam 6 tahun & $(5)$ \\
3 & Perusahaan Industri yang menerbitkan lengkap laporan keuangan & 10 \\
4 & Perusahaan industri yang mengalami kerugian & $(3)$ \\
5 & Perusahaan Industri yang aktif dalam kurun waktu tahun 2010 - 2015 & 7 \\
& tota seluruh sampel dalam 6 tahun & 42 \\
\hline
\end{tabular}

Sumber : data yang diolah dalam penelitian

Penelitian menggunakan variabel inde- kebijakan dividen (Z2), serta agresivitas pajak penden yaitu gross profit margin (X1), variabel perusahaan sebagai variabel dependen (Y), dapat mediating yaitu financial leverage (Z1), dilihat dari variabel operasional berikut :

Tabel. 4. Operasionalisasi variabel

\begin{tabular}{|c|c|c|c|}
\hline Variabel & Sub Variabel & Definisi & Pengukuran \\
\hline $\begin{array}{l}\text { Gross Profit } \\
\text { Margin (X1) }\end{array}$ & $\begin{array}{l}\text { Gross Profit } \\
\text { Margin }\end{array}$ & $\begin{array}{l}\text { Gross profit margin yang dimaksud adalah } \\
\text { rasio penjualan setelah dikurangi harga } \\
\text { pokok penjualan (cost of goods sold) } \\
\text { dengan nilai penjualan bersih perusahaan } \\
\text { (Abdullah,2005:54). }\end{array}$ & $\begin{array}{c}\text { Net Sales - Cost of } \\
\text { Goods Sold } \\
\text { Net Sales }\end{array}$ \\
\hline $\begin{array}{l}\text { Agresivitas } \\
\text { Pajak } \\
\text { (Y1) }\end{array}$ & $\begin{array}{l}\text { Benchmarking } \\
\text { (NPM jenis } \\
\text { usaha yang } \\
\text { sama) }\end{array}$ & $\begin{array}{l}\text { Ukuran tingkat agresivitas pajak yang } \\
\text { dilakukan perusahaan diproksikan dengan } \\
\text { membandingkan Net profit margin (NPM) } \\
\text { dalam perusahaan dengan Net profit margin } \\
\text { (NPM) dari industri perusahaan tersebut (Ida } \\
\text { Bagus Putu Fajar Adisamartha 2015). }\end{array}$ & $\begin{array}{l}\text { NPM indeks = } \\
\text { NPM Perusahaan } \\
\text { NPM Benchmarking }\end{array}$ \\
\hline $\begin{array}{l}\text { Financial } \\
\text { leverage } \\
\text { (Z1) }\end{array}$ & $\begin{array}{c}\text { Debt To Equity } \\
\text { Ratio (DER) }\end{array}$ & $\begin{array}{l}\text { Menunjukkan kemampuan perusahaan } \\
\text { dalam membayar hutang dengan ekuitas } \\
\text { yang dimilikinya. Rasio ini menggambarkan } \\
\text { perbandingan hutang dan ekuitas dalam } \\
\text { pendanaan perusahaan dan menunjukkan } \\
\text { kemampuan modal sendiri perusahaan } \\
\text { tersebut untuk memenuhi seluruh kewajiban- } \\
\text { nya (kasmir,2012:158). }\end{array}$ & $\begin{array}{l}\text { Total Kewajiban } \\
\text { Tota Ekuitas }\end{array}$ \\
\hline $\begin{array}{l}\text { Kebijakan } \\
\text { Dividen } \\
\text { (Z2) }\end{array}$ & $\begin{array}{l}\text { Dividend } \\
\text { (DIV) }\end{array}$ & $\begin{array}{l}\text { Kebijakan dividen ialah kebijakan yang } \\
\text { berhubungan dengan pembayaran dividen } \\
\text { oleh pihak perusahaan, berupa penentuan } \\
\text { besarnya dividen yang akan dibagikan dan } \\
\text { besarnya saldo laba yang ditahan untuk } \\
\text { kepentingan perusahaan (Rosdini, 2009). }\end{array}$ & $\begin{array}{l}\text { Dummy Cash } \\
\text { Dividend, } 1 \text { jika } \\
\text { perusahaan membayar } \\
\text { dividend dan } 0 \text { untuk } \\
\text { sebaliknya }\end{array}$ \\
\hline
\end{tabular}

Sumber : data yang digunakan dalam penelitian 


\section{Hasil Penelitian dan Pembahasan}

Data deskriptif statistik dalam penelitian ini bisa dilihat pada tabel 5

Tabel 5. Deskriptif statistik

\begin{tabular}{lllll}
\hline & Tax_AGG & LEV & DIV & GPM \\
\hline Mean & 0,88 & 0,92 & 0,52 & 0.26 \\
Maksimum & 1,52 & 1,75 & 1 & 0.53 \\
Minimum & 0,052 & 0,25 & 0 & 0.06 \\
Std Deviasi & 0,39 & 0.43 & 0,51 & 0.11 \\
\hline
\end{tabular}

Sumber : data diolah digunakan dalam penelitian ini.

Nilai rata-rata gross profit margin sebesar $26 \%$ dan nilai rata-rata financial leverage sebesar 92\%, menunjukkan bahwa perusahaan dengan rata-rata gross profit sebesar tersebut lebih memanfaatkan hutang sebagai pembiayaan perusahaannya. Nilai rata-rata kebijakan dividen sebesar 51\%, menunjukkan tidak semua perusahaan dalam sampel penelitian melakukan kebijakan dividen setiap tahunnya.

Nilai rata-rata agresivitas pajak perusahaan sebesar $88 \%$ menunjukkan perusahaan rata-rata menghasilkan tingkat net profit margin yang hampir sebanding dengan standar net profit margin untuk perusahaan sejenis oleh data yang dikeluarkan oleh Direktorat Jenderal Pajak.

\section{Pengujian Hubungan gross profit margin dengan agresivitas pajak}

Pengujian hubungan gross profit margin dengan agresivitas dilakukan dalam 2 bagian yaitu :

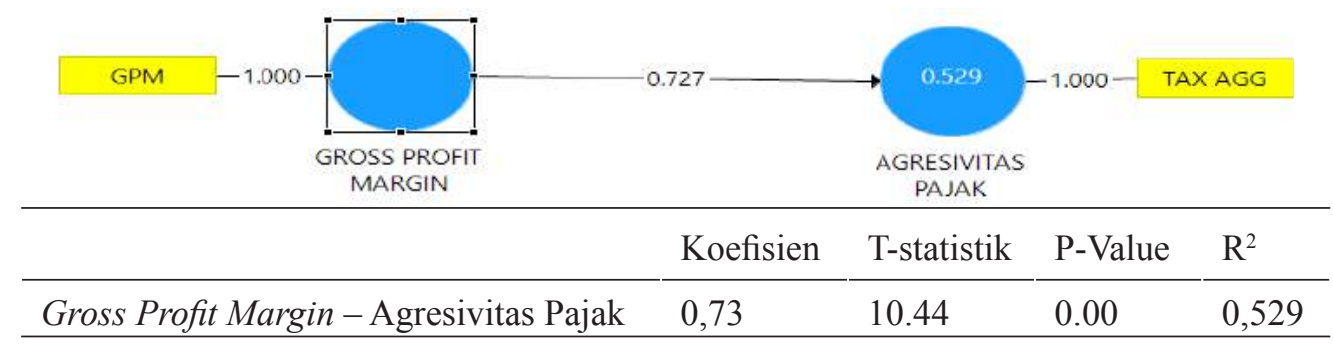

Gambar 4. Pengaruh gross profit margin terhadap agresivitas pajak tanpa variabel mediasi

Pada gambar menunjukkan bahwa gross profit margin berpengaruh terhadap agresivitas pajak perusahaan sebelum dimediasi oleh kebijakan dividen.

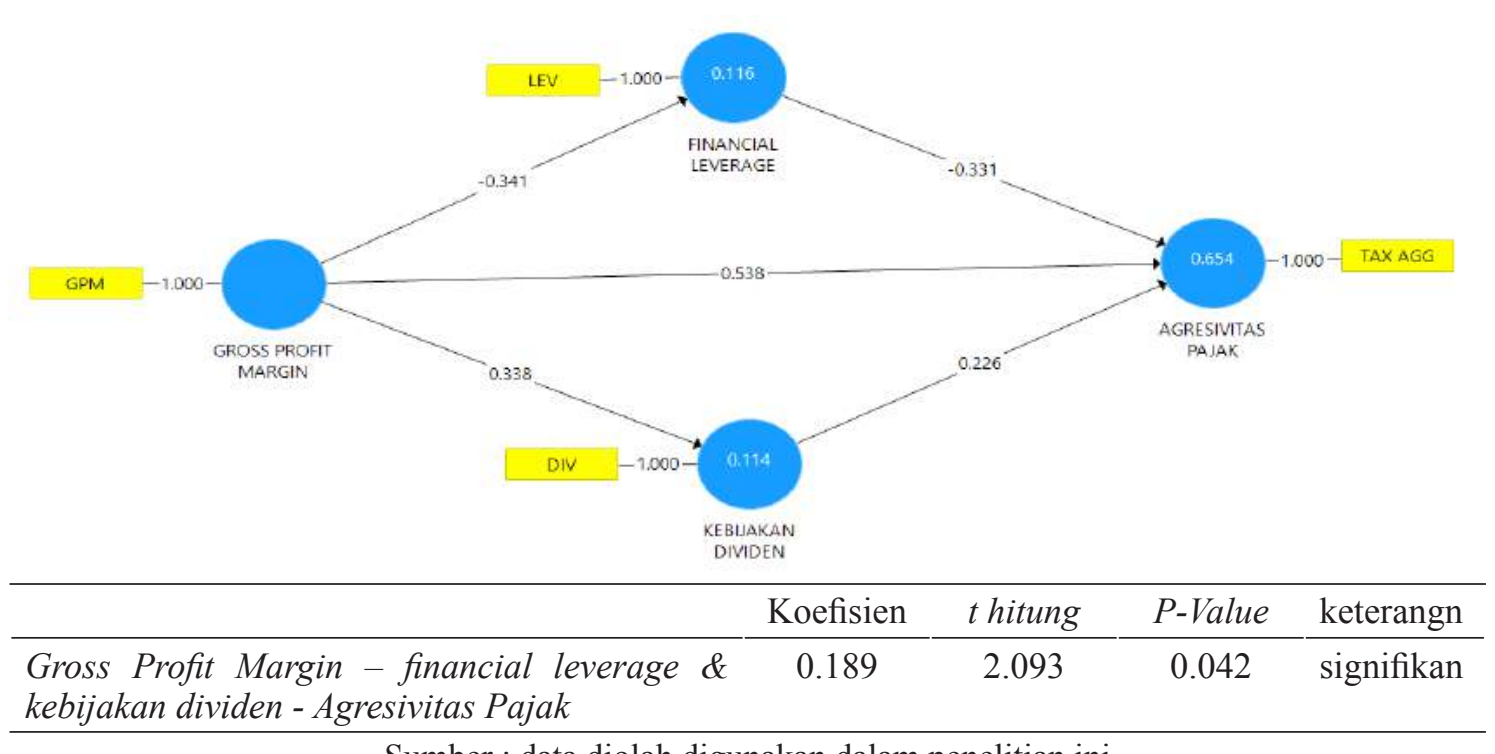

Sumber : data diolah digunakan dalam penelitian ini

Gambar 5. Pengaruh gross profit margin terhadap agresivitas pajak dengan mediasi financial leverage dan kebijakan dividen 
Pada gambar 5 menunjukkan bahwa gross profit margin berpengaruh positif signifikan terhadap agresivitas pajak perusahaan setelah dimediasi oleh kebijakan dividen.

\section{Nilai R-Squar0e}

Nilai $\mathrm{R}^{2}$ mengindikasikan bahwa model masuk dalam kategori "baik; 0,67, "Moderat ; 0,33 dan lemah; 0,19 . Hasil $\mathrm{R}^{2}$ dalam penelitian dapat ditunjukkan sebagai berikut :

Tabel 7. Nilai R-Square

\begin{tabular}{llll}
\hline Path Analysis & $\mathrm{R}^{2}$ & Kategori \\
\hline Gross Profit Margin - Agresvitas Pajak & 0.529 & baik \\
Gross Profit Margin - financial leverage & 0.116 & lemah \\
Gross Profit Margin - kebijakan dividen & 0.114 & lemah \\
Gross Profit Margin - financial leverage dan kebijakan dividen - Agresvitas Pajak & 0.654 & baik \\
\hline
\end{tabular}

Sumber : data diolah digunakan dalam penelitian

Nilai $\mathrm{R}^{2}$ menunjukkan bahwa gross profit margin dengan mediasi financial leverage dan kebijakan dividen menyumbang pengaruh terhadap agresivitas pajak sebesar $65,4 \%$ sisanya $34.6 \%$ dipengaruhi faktor lainnya misalnya hubungan istimewa dengan biaya intercompany dan faktor lainnya.

\section{Efek Mediasi}

efek mediasi terjadi dari dua mediating dapat umus $\mathrm{f}^{2}$ ( Nilai effect size) berikut :

$$
f^{2}=\frac{R^{2} \text { withmediator }-R^{2} \text { withoutmediator }}{\begin{array}{c}
1-R^{2} \text { withmediator } \\
\text { Rumus effoct size }
\end{array}}
$$

Menurut Cohen (1988) nilai effect size : $0.02-0.15$ (lemah), $0.15-0.35$ (sedang) dan $>0.35$ (kuat). Sehingga dari perhitungan diatas dapat diperoleh hasil 36,1\% dengan efek mediasi

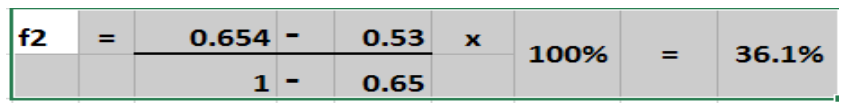

kategori kuat.

Hasil pengujian hipotesis hubungan gross profit margin dengan agresivitas pajak secara full model dapat terlihat pada tabel berikut :

Tabel 8. Hasil pengujian hiptesis direct effect dan indirect effect

\begin{tabular}{|c|c|c|c|c|}
\hline \multirow{2}{*}{ Path } & \multicolumn{3}{|c|}{ Direct Effect } & \multirow{2}{*}{ Hasil } \\
\hline & Koefisien & thitung & $P$-Value & \\
\hline Gross profit margin - Financial leverage & -0.341 & 2.289 & 0.022 & signifikan \\
\hline Gross profit margin - Kebijakan Dividen & 0.338 & 2.444 & 0.015 & signifikan \\
\hline Financial leverage - agresivitas pajak & -0.331 & 3.218 & 0.001 & signifikan \\
\hline Kebijakan dividen - agresivitas pajak & 0.226 & 1.983 & 0.048 & signifikan \\
\hline Gross Profit Margin - Agresivitas Pajak & 0.538 & 4.818 & 0.000 & signifikan \\
\hline \multirow{2}{*}{ Path } & \multicolumn{3}{|c|}{ Indirect Effect } & Hasil \\
\hline & Koefisien & thitung & P-Value & Hasil \\
\hline $\begin{array}{l}\text { Gross Profit Margin - financial leverage \& } \\
\text { Kebijakan dividen - Agresivitas Pajak }\end{array}$ & 0.189 & 2.093 & 0.042 & $\begin{array}{l}\text { signifikan } \\
\text { part mediation }\end{array}$ \\
\hline
\end{tabular}

Sumber : data diolah digunakan dalam penelitian ini 


\section{Pengaruh gross profit margin terhadap financial leverage}

Hasil penelitian menunjukkan gross profit margin berpengaruh negatif signifikan terhadap financial leverage. Gambaran secara umum bahwa perusahaan food and beverage selama tahun 2010 sampai dengan 2015 mengalami penurunan gross profit margin yang diimbangi dengan kenaikan hutang yang tinggi Perusahaan food and beverage selama tahun 2010.

Hubungan negatif antara profitabilitas dengan hutang, dimana kenaikan profit akan mendorong perusahaan menu-runkan penggunaan hutang sejalan dengan penelitian yang dilakukan oleh Indahningrum dan Handayani (2009), Ismayanti dan Hanafi (2003). Myers et al (1984), Jensen et al (1992) dan Moh'ed et al (1998) dan Nurbaiti (2007) menemukan adanya pengaruh negatif dan signifikan antara profitabilitas terhadap pilihan me-lakukan kebijakan hutang.

\section{Pengujian pengaruh gross profit margin terhadap kebijakan dividen}

Hasil penelitian menunjukkan bahwa gross profit margin berpengaruh signifikan terhadap kebijakan dividen. Rendahnyagross profitmargin mendorong perusahaan tidak selalu melakukan kebijakan dividen, kondisi sebaliknya terjadi bila profitabilitas tinggi mendorong perusahaan melakukan kebijakan dividen, sejalan dengan penelitian Jensen, Solberg, dan Zorn (1992), semakin tinggi laba maka semakin tinggi aliran kas dalam perusahaan sehingga perusahaan dapat membayar dividen lebih tinggi

\section{Pengujian pengaruh financial leverage terhadap agresivitas pajak}

Hasil penelitian menunjukkan bahwa financial leverage berpengaruh signifikan terhadap agresivitas pajak perusahaan, setiap kenaikan leverage mengakibatkan terjadinya penurunan rasio agresivitas pajak sebagai akibat turunnya net profit margin perusahaan dibanding net profit margin sejenis yang mengindikasikan meningkatnya tindakan agresivitas pajak perusahaan.

Secara umum dapat dikatakan bahwa kondisi perusahaan food and beverage selama tahun 2010 sampai dengan 2015 sebagain besar melakukan kebijakan hutang (financial leverage) yang ditunjukan oleh rasio hutang yang tinggi sebesar $92 \%$ yang mengkondisikan perusahaan banyak mengandalkan hutang dibandingkan modal yang ada. Kondisi ini diimbangi oleh tindakan agresivitas pajak yang tinggi bila dilihat dari net profit margin yang dihasilkan oleh perusahaan masih dibawah standar net profit margin benchmarking ( kondisi perusahaan melakukan tindakan agresivitas pajak.

Peningkatan hutang berpengaruh signifikan terhadap kondisi tindakan agresivitas pajak perusahaan menandakan adanya bentuk penghematan pajak yang dilakukan oleh perusahaan, sebagaimana ketahui bahwa tindakan agresivitas pajak tidak hanya terbatas pada tax evasion (penggelapan pajak) namun juga dilakukan dengan tax avoidance. Tindakan agresivitas pajak dengan cara pemanfaatkan leverage yang berimbas adanya pengurangan laba usaha dari biaya bunga yang dibebankan menjadi suatu pilihan yang menarik buat perusahaan.

Penelitian Ozkan (2001) memberikan bukti bahwa perusahaan yang memiliki kewajiban pajak tinggi akan memilih untuk berutang agar mengurangi pajak. Hal ini sejalan dengan penelitian Suyanto dan Supramono (2012) yang menjelaskan bahwa leverage perusahaan manufaktur berpengaruh positif dan signifikan terhadap agresivitas pajak perusahaan, atau dengan kata lain adanya pengaruh yang kuat antara leverage perusahaan terhadap tingkat agresivitas pajak perusahaan, dimana semakin tinggi leverage maka semakin tinggi agresivitas pajak perusahaan.

Hasil penelitian menunjukkan pengaruh signifikan antara peningkatan hutang dengan peningkatan tindakan agresivitas pajak juga 
sejalan dengan trade-off teory yang diungkapkan oleh Miller (1958) "Perusahaan akan berhutang sampai pada tingkat hutang tertentu, dimana penghematan pajak (tax shields) dari tambahan hutang sama dengan biaya kesulitan keuangan (financial distress)" (p.81). Trade-off theory mempunyai implikasi bahwa manajer akan berpikir dalam kerangka trade-off antara penghematan pajak dan biaya kesulitan keuangan dalam penentuan struktur.

\section{Pengujian pengaruh kebjakan dividen terhadap agresivitas pajak}

Hasil penelitian bahwa kebijakan dividen berpengaruh signifikan negatif terhadap agresivitas pajak perusahaan, setiap peningkatan kebijakan dividen yang diambil mengakibatkan peningkatan rasio agresivitas pajak (tindakan agresivitas pajak menurun).

Berdasarkan fenomena awal bahwa tidak semua didapati perusahaan walaupun dalam kondisi laba, mengambil kebijakan dividen, berbeda dengan fenomena leverage yang selalu dipilih oleh perusahaan. Dari 7 perusahaan yang diteliti dalam 6 tahun hanya 50\% yang melakukan kebijakan dividen ditahun tersebut, Sedangkan bila dibandingkan dengan rata-rata rasio kebijakan dividen dan rasio agresivitas selama tahun pajak 2010 -2015 dapat diketahui bahwa rata rata rasio kebijakan dividen sebesar $52 \%$ sedangkan rasio rata-rata agresivitas pajak menunjukkan $88 \%$, tindakan agresivitas pajak yang ditunjukkan oleh rasio tersebut menggambarkan bahwa rata rata perusahaan melaporkan net profit marginnya (laba) tidak semua perusahaan yang mengalami laba melakukan kebijakan dividen.

Kebijakan dividen berbeda sifatnya bila dikaitkan dengan sudut pandang peraturan perpajakan. Bila financial leverage menimbulkan biaya bunga yang berpotensi mengurangi beban pajak yang terhutang karena sifatnya yang deductable, sedangkan kebijakan dividen adalah pembagian dividen yang berasal dari laba setelah pajak perusahaan kepada pemilik saham dalam hal investasi penanaman modal yang dilakukan, namun karena kewajiban perpajakan di Indonesia menganut bahwa antara perusahaan dengan pemilik modal merupakan entitas yang berbeda, sehingga pada saat pemilik modal menerima penghasilan dividen maka jumlah yang diterima harus di kurangi dengan pajak dividen atas pemilik saham.

\section{Pengujian pengaruh gross profit margin terhadap agresivitas pajak}

Hasil penelitian menunjukkan bahwa penurunan gross profit margin meng-akibatkan penurunan pada rasio agresivitas pajak (tindakan agrsivitas pajak naik).

Secara umum dapat dikatakan bahwa kondisi perusahaan food and beverage selama tahun 2010 sampai dengan 2015 dalam kondisi gross profit margin yang rendah yang ditunjukkan oleh rasio $26 \%$ hal ini mendorong tindakan agresivitas pajak perusahaan (kondisi perusahaan memiliki net profit margin yang lebih rendah dibandingkan dengan net profit margin benchmarking yang dikeluarkan oleh Direktorat Jenderal Pajak.

Perusahaan yang profitability dengan kenaikan laba kotor yang meningkat merupakan awal yang baik untuk mencerminkan kesehatan keuangan perusahaan ter-sebut. Hal ini karena profitabilitas meru-pakan kemampuan perusahaan untuk menghasilkan laba atau nilai hasil akhir dari kegiatan operasional perusahaan selama periode tertentu. Perusahaan dengan profitabilitas yang rendah akan memiliki kemungkinan yang tinggi untuk tidak taat membayar pajak. Hal ini karena perusahaan dengan profitabilitas yang rendah akan memilih untuk mempertahankan keadaan keuangan dan aset perusahaan daripada membayar pajak, sehingga perusahaan tersebut menjadi agresif terhadap pajak.

Pendapat yang sama juga diungkapan oleh Rodiguez dan Arias (2012) hubungan antara profitabiltas dan effective tax ratio (salah satu alat ukur agresivitas pajak perusahaan) bersifat 
langsung dan signifikan. Tingkat pendapatan cenderung berbanding lurus dengan pajak yang dibayar. meningkatnya profitabilitas suatu perusahaan dapat disebabkan oleh meningkatnya kapasitas perusahaan atau sumber pendanaan dalam menjalankan aktivitas bisnis (Natalia, 2012).

\section{Pengujian Pengaruh Gross profit margin terhadap agresivitas pajak dimediasi oleh financial leverage dan kebijakan dividen}

Berdasarkan fenemena yang terjadi bahwa perusahaan food and beverage selama tahun 2010-2015 rata-rata gross profit margin perusahaan yang rendah sebesar $26 \%$ dengan rata-rata financial leverage yang tinggi sebesar $92 \%$ dan kebijakan dividen yang dilakukan hanya sebesar $52 \%$ serta terjadinya agresivitas pajak yang ditandai oleh rasio net profit margin yang dihasilkan oleh perusahaan lebih rendah dibandingkan standar net profit margin dalam benchmarking yang dikeluarkan oleh Direkrorat Jenderal Pajak (rasio 88\%).

Bila dihubungkan antara fenomena dengan hasil statistik penelitian dapat menjelaskan bahwa kondisi rasio gross profit margin yang rendah mendorong perusahaan untuk melakukan peningkatan pada financial leverage artinya sebagian besar modalnya dibiayai oleh hutang. Gross profit margin yang rata-rata rendah juga menyebabkan tidak semua perusahaan dalam kondisi laba melakukan kebijakan dividen. Sehingga kondisi gross profit margin yang rendah, tingkat financial leverage yang tinggi dan pilihan perusahaan untuk tidak selalu membagikan dividen tiap tahun mendorong penurunan rasio agresivitas pajak (tindakan agresivitas pajak meningkat).

\section{Simpulan, Keterbatasan, dan Implikasi Hasil Penelitian}

Gross profit margin berpengaruh negatif terhadap finacial leverage. Kondisi gross profit margin yang rendah berpengaruh terhadap financial leverage yang tinggi yang ditunjukkan oleh rasio hutang yang tinggi artinya pendanaan perusahaan hampir sebagaian besar menggunakaan hutang. Gross profit margin berpengaruh positif terhadap kebijakan dividen - Kondisi gross profit margin yang rendah secara rata-rata menyebabkan hanya sebagian perusahaan memilih melakukan kebijakan dividen. Financial leverage berpengaruh positif terhadap agresivitas pajak. Kondisi perusahaan yang lebih banyak menggunakan hutang dibandingkan modal mempengaruhi perusahaan menjadi lebih agresif terhadap pajak yang ditunjukkan oleh rasio net profit margin yang dimiliki perusahaan masih dibawah ratarata benchmarking yang dikeluarkan oleh Direktorat Jenderal Pajak. Kebijakan dividen berpengaruh negatif terhadap agresivitas pajak. kondisi yang ada hanya sebagian perusahaan melakukan kebijakan dividen, Keengganan perusahaan untuk melakukan kebijakan dividen mempengaruhi kondisi perusahaan bertindak lebih agresif (tindakan agresivitas pajak naik).

Gross profit margin berpengaruh negatif terhadap tindakan agresivitas pajak. Kondisi gross profit margin yang masih rendah mempengaruhi perusahaan untuk melakukan tindakan agresivitas pajak yang ditunjukkan net profit margin yang dihasilkan oleh perusahaan masih dibawah rata-rata benchmarking. Gross profit margin berpengaruh negatif terhadap tindakan agresivitas pajak saat dimediasi oleh financial leverage dan kebijakan dividen. Hal ini mengindikasikan bahwa kondisi gross profit margin yang masih rendah mempengaruhi peningkatan hutang dan keengganan perusahaan untuk melakukan kebijakan dividen yang akhirnya berimbas pada tindakan perusahaan menjadi lebih agressif terhadap pajak.

Penelitian ini hanya mencakup periode penelitian selama 6 tahun yaitu mulai tahun 2010 sampai dengan tahun 2015 sehingga penelitian masih dalam waktu yang terbatas dan belum digeneralisasi untuk periode yang lebih panjang. Pada dasarnya pengukuran agresivitas pajak dapat menggunakan skala pengukuran 
yang umumnya dilakukan peneliti sebelumnya yaitu menggunakan Efektif Taxs Ratio (ETR), Cash Efektif Taxs Ratio (CETR) dan Book Taxs Difference (BTD), akan tetapi penelitian ini hanya menggunakan rasio Net Profit Margin perusahaan dibandingkan Net Profit Margin dalam benchmarking yang dikeluarkan oleh Direktorat Jenderal Pajak.

Hubungan gross profit margin dengan tindakan agresivitas pajak yang dimediasi oleh financial leverage dan kebijakan dividen, disarankan penelitian selanjutnya menggunakan variabel lain seperti beban intercompany yang banyak berhubungan dengan biaya-biaya yang muncul dari kebijakan hutang, financial flexibility Kontribusi penelitian dimana hubungan gross profit margin dengaan tindakan agresivitas pajak yang dimediasi oleh kebijakan hutang dan kebijakan dividen dapat memberikan signal terhadap pemilik dana (shareholder) terhadap penempatan modal pada perusahaan yang melakukan tindakan agresivitas pajak, dan bagi regulator dapat menjadi pertimbangan perumusan peraturan penetapan hutang dan dividen terkait dengan efek pembayaran pajak yang ditimbulkan dari tindakan agresivitas pajak.

\section{Daftar Referensi}

Abdullah, M. Faisal, 2005. Dasar-dasar Manajemen Keuangan, edisi kedua. Universitas Muhamadiyah, Malang.

Adisamartha, Ida Bagus Putu Fajar dan Noviari, Naniek, 2015. Pengaruh Likuiditas, Leverage, Intensitas Persediaan dan Intensitsa Aset Tetap Pada tingkat Agresivitas Wajib Pajak Badan, E-Jurnal Akuntansi Universitas Udayana, Vol. 13.3 Desember (2015): 973-1000.

Choi, Y.R. 2003. Taxes and Corporate Capital Structure.Journal of Finance, 11(1).

Dwi Suyanto, Krisnata. Supramono, 2012. Likuiditas, Leverage, Komisaris Independen, Dan Manajemen Laba Terhadap Agresivitas Pajak Perusaahaan, Jurnal
Keuangan dan Perbankan, Vol.16, No.2 Mei 2012, hlm. 167-177.

Frank, M., Lynch, L., dan Rego, S. 2009. Tax reporting aggressiveness and its relation to aggressive financial reporting. The Accounting Review, 84, 467-496.

Fontanella, A., \& Martani, D., 2014, Pengaruh Karakteristik Perusahaan terhadap Book Tax Differences (BTD) pada Perusahaan Listed di Indonesia, Makalah dipresentasikan pada Simposium Nasional Akuntansi (SNA) 17. Mataram Ghozali, Imam. (2012) Aplikasi Analisis Multivariate dengan Program SPSS. Edisi Enam. Semarang: Badan Penerbit Universitas Diponegoro .

Husnan, Suad. 2010. Manajemen Keuangan Teori dan Penerapan (Keputusan Jangka Panjang) Buku 1. Yogyakarta: BPFE.

Ikatan Akuntansi Indonesia, 2009, Standar Akuntansi Keuangan, Penerbit Salemba Empat, Jakarta.

Kurniasih, Tommy dan Maria M.Ratna Sari. (2013) Pengaruh Return on Assets, Leverage, Corporate Governance, Ukuran Perusahaan Dan Kompensasi Rugi Fiskal Pada Tax Avoidance,. Buletin Studi Ekonomi. (18). hal. 58-66.

Kamila PutriAlamaida, 2014, Analisis hubungan agresivitas pelaporan dan keuangan dana gresivitas pajak, Finance adn Banking Journal, Vol 16 No. 2 Desember 2014

Kasmir, 2008, Analisis Laporan Keuangan, Rajawali Pers, Jakarta.

Latan, H., dan Ghozali. 2012 Partial Least Square Konsep, Metode dan Aplikasi Menggunakan Program WarpPLS 2.0. Badan Penerbit Universitas Diponogoro, Semarang.

Modigliani, Franco, and Miller, Merton H., 1958, The Cost of Capital, Corporate Finance, and the Theory of Investment, the American Economic Review, 48/3, 261 - 297.

Ngadiman, Puspitasari, 2014. Pengaruh Leverage, kepemilikan Institusional, Dan 
Ukuran Perusahaan Terhadap Penghindaran Pajak (Tax Avoidance). Pada Perusahaan Sektor Manufaktur Yang Terdaftar di Bursa Efek Indonesia 20102012, Jurnal Akuntansi/Volume XVIII, No. 03, September 2014: 408-421.

Ozkan, A. 2001. Determinants of Capital Structure and Adjustment to Long-run Target: Evidence from UK Company Panel Data. Journal of Business Finance and Accounting, 28: 175-199.

Prihandini, Wiwiek (2010), Pajak Badan Dan Kebijakan Deviden: Dalam Perspektif Corporate Governance Studi pada Perusahaan yang Tercatat pada Bursa Efek Indonesia dan Jakarta Islamic Index (JII) 2010, Jurnal Ekonomi \& Bisnis Islam, Vol. VI, No. 2, Juni 2012 ISSN 1907-9109.

Pohan, Hotman T. (2009), Analisis Pengaruh Kepemilikan Institusi, Rasio Tobin Q, Akrual Pilihan, Tarif Efektif Pajak, Dan Biaya Pajak Ditunda Terhadap Penghindaran.

Prihandini Wiwiek,2012, Pajak Badan Dan Kebijakan Deviden: Dalam Perspektif Corporate Governance Studi pada Perusahaan yang Tercatat pada Bursa Efek Indonesia dan Jakarta Islamic Index (JII) 2010, Jurnal Ekonomi \& Bisnis Islam, Vol. VI, No. 2, Juni 2012 ISSN 1907-9109.

Richardson, Grant dan Roman Lanis. (2007). Determinants of the variability in corporate effective tax rates and tax reform: Evidence from Australia". Journal of Accounting and Public Policy. (26). hal. 689-704.

Ross, Westerfield, Jaffe, and Jordan. 2008, Modern Financial Management, $8^{\text {th }}$ Edition. McGraw-Hill.

Rosdini, D. 2009. Pengaruh Free Cash Flow Terhadap Dividend Payout Ratio. Paper. Fakultas Ekonomi Universitas Padjajaran.

Sari, Dewi Kartika dan Dwi Martani, 2010, Karekteristik Kepemilikan Perusahaan, Corporate Governance, Tindakan Agresif, Jurnal Akutansi. PP 1-32.
Sari, D.K. \& Martani, D. 2010. Ownership Characteristics, Corporate Governance and Tax Aggressiveness. The 3rd International Accounting Conference \& The 2nd Doctoral Colloquium. Bali.

Sirait, N.S. \& Martani, D. 2014.Pengaruh Perusahaan Keluarga terhadap Penghindaran Pajak pada Perusahaan Manufaktur di Indonesia dan Malaysia. Makalah dipresentasikan pada Simposium Nasional Akuntansi (SNA) 17. Mataram.

Suyanto, Krisnata Dwi dan Supramono 2012. Likuiditas, Leverage, Komisaris Independen, dan Manajemen Laba terhadap Agresivitas Pajak Perusahaan. Jurnal Keuangan dan Perbankan, Vol.16, No.2 Mei 2012, hlm. 167-177.

Undang-Undang Republik Indonesia Nomor 36 Tahun 2008 Tentang Perubahan Keempat Atas Undang-Undang Nomor 7 Tahun 1983 Tentang Pajak Penghasilan.

Thaib Chaidir dan Taroreh Rita, 2015. Pengaruh kebijakan hutang dan dividen profitabilitas terhadap kebijakan dividen (studi pada perusahaan food and beverage yang terdaftar di BEI tahun 2010-2014), Jurnal EMBA Vol.3 No.4 Desember 2015, Hal. 215-225.

Van Horne, James C. Dan M. Jhon Wachowicz, 2005. Prinsip-Prinsip Manajemen Keuangan, Diterjemahkan oleh Aria Farahmita, Amanugrani, dan Taufik Hendrawan, edisis kedua belas, PT.Salemba Empat, Buku Satu, Jakarta.

Zhou Ying (2011). Ownership Structure, Board Characteristics, and Tax Aggressiveness. Thesis Lingnan University.

Zimmerman, J. 1983. Taxes and firm size. Journal of Accounting and Economics, 5 (2), 119-149. 